\title{
頭痛・高血圧を指標とした釣藤散の耳鳴治療
}

\author{
斎藤晶

\section{Clinical Efficacy of Choto-san in the Treatment of Tinnitis}

\author{
Akira Saito \\ (Social Insurance of Saitama Chuou Hospital)
}

Forty patients with tinnitus were treated by Choto-san.

1) The curative rate of those groups receiving treatment based on the clinical diagnosis of the disease and based on SHO was $47.8 \%$ and $76.8 \%$, respectively.

2) There was no significant difference in efficacy between those patients with hypertension or headache.

3) There was a signifficant difference in efficacy between those patients over 70 years of age and those under 70 years old.

Careful observation of the indications for treatment are essential, and treatments based on SHO were more effective.

Key words : Choto-san, tinnitus, hypertension, headache, SHO

はじめに

漢方薬により治療する際は, 適応を守ること, さらに は証を考慮することが必要である. ツムラ釣藤散エキス 顆粒 ${ }^{\circledR}$ は，適応が「慢性に続く頭痛で中年以降，または 高血圧の傾向のあるもの」であり耳鳴の適応はないが, 耳鳴治療の報告が散見される1) 3). 今回, 釣藤散を耳鳴 に投与し，随証治療の有無，高血圧・頭痛の有無による 治療効果を検討した。

\section{対象・方法}

社会保険埼玉中央病院耳鼻咽喉科を受診し耳鳴の訴兄 のある患者 40 名に釣藤散を投与し，1 カ月以上経過が追 えた症例, または副作用のため中止した症例を retrospective に調べた。耳鳴に対して病名治療(耳鳴があるので 釣藤散を投与) し，再診時に頭痛・高血圧のいずれもな い群を $\mathrm{A}$ 群, 病名治療し, 再診時に頭痛・高血圧のいず れかが確認できた群を $\mathrm{B}$ 群, 随証治療した群をC 群とし た. 耳鳴の治療効果は, 患者の訴えにより, 消失・改善

・不変の 3 段階に評価した.

\section{結＼cjkstart果(表 1)}

1) 群構成および群別結果

A群は，13例で男性 8 例，女性 5 例であり，平均年齢 は58.3歳であった. 消失 1 例, 改善 5 例, 不変 7 例であ った． 1 例が顔面浮腫のため投薬を中止し，その時点で 耳鳴は不変であった。消失と改善をあわせた改善以上は $46.2 \%$ であった。 B群は, 10例で, 男性 4 例, 女性 6 例 であり, 平均年齡は63.3歳であった. 消失 1 例, 改善 4

\section{表 1 群別治療効果}

\begin{tabular}{c|c|c|c|c}
\hline \hline 群 & 消 失 & 改 善 & 不 変 & 計 \\
\hline $\mathrm{A}$ & 1 & 5 & 7 & 13 \\
$\mathrm{~B}$ & 1 & 4 & 5 & 10 \\
$\mathrm{C}$ & 2 & 11 & 4 & 17 \\
\hline 計 & 4 & 20 & 16 & 40
\end{tabular}


例，不変 5 例であり, 改善以上は $50.0 \%$ であった．A群 とB群を併せた病名治療群の改善以上は47.8\%であった。 $\mathrm{C}$ 群は17例で, 男性 8 例, 女性 9 例であり, 平均年龄は 62.8 歳であった. 消失 2 例, 改善 11 例, 不変 4 例であり, 改善以上は $76.8 \%$ であった。 40例全体では，改善以上は 60.0\%であった。

2 ）高血圧・頭痛の有無と治療効果 (表 2 )

処方時・再診時のいずれかで高血圧が確認された群は 22 例で, 耳鳴は消失 2 例, 改善 13 例, 不変 7 例であった. 高血圧がない群は，18例で，耳鳴は消失 2 例，改善 7 例， 不変 9 例であった．頭痛が確認された群は，20例で，消 失 2 例, 改善 10 例, 不变 8 例であった. 頭痛がない群は 10 例で, 消失 2 例, 改善10例, 不変 8 例であった. 頭痛・ 高血圧の有無で治療効果に差を認めなかった。

3 ) 年齢と治療効果 (表 3 )

5 歳毎に年齢を区切って治療効果を調べると， 70〜 74 歳で治療効果が優れていた.70歳以上と70歳未満では, 有効以上がそれぞれ $84.7 \% ， 48.1 \%$ であり有意差を認め た $(\mathrm{p}<0.05)$.

表 2 高血圧・頭痛の有無と治療効果

\begin{tabular}{|c|c|c|c|c|c|}
\hline 指 & 標 & 消 失 & 改 善 & 不 変 & 計 \\
\hline \multirow[t]{2}{*}{ 高血圧 } & あり & 2 & 13 & 7 & 22 \\
\hline & なし & 2 & 7 & 9 & 18 \\
\hline \multirow[t]{2}{*}{ 頭＼cjkstart痛 } & あり & 2 & 10 & 8 & 20 \\
\hline & なし & 2 & 10 & 8 & 20 \\
\hline
\end{tabular}

表 3 年齢と治療効果

\begin{tabular}{r|c|c|c}
\hline \hline 年 齢 & 消 失 & 改 善 & 不 変 \\
\hline$\sim 75$ & 0 & 2 & 1 \\
$74 \sim 70$ & 1 & 8 & 1 \\
$69 \sim 65$ & 1 & 3 & 5 \\
$64 \sim 60$ & 0 & 3 & 2 \\
$59 \sim 55$ & 0 & 1 & 2 \\
$54 \sim 50$ & 2 & 2 & 3 \\
$49 \sim 45$ & 0 & 0 & 1 \\
$44 \sim 40$ & 0 & 1 & 0 \\
$39 \sim 35$ & 0 & 0 & 0 \\
$34 \sim$ & 0 & 0 & 1
\end{tabular}

\section{考 察}

漢方薬による治療は 2 つの方法がある.1つには西洋 医学的な薬効薬理から処方する場合があり，小形ら4)が 柴胡桂枝湯の抗痤攣作用を応用して耳鳴治療を行った例 がある。も51つは東洋医学的な考光にもとづいて処方 する場合である。このとき，証を考虑することが望まれ る. 的確な治療効果を得るため, 食欲不振, 下痢, のぼ せなどの副作用防止のため，さらに副作用が出現した場 合も随証治療していれば医師の責任は軽減する可能性が あるためなどの理由による，実際の外来では，病名治療， 参考とする症状を指標とした治療，随証治療のいずれか が行われている．耳鳴を釣藤散で治療する場合，参考と する症状は適応にある頭痛・高血圧である。

耳鳴を蔵腑弁証により論ずると, 肝, 腎, 脾が関与す る. 肝は気の昇降・出入の調節をしておうり,この機能に 障害が起きると気が上えし耳鳴となる．肝火上炎には柴 胡加竜骨牡蚛湯，肝陽上六には釣藤散が処方される．腎 の精気が衰えると，難聴・耳鳴をきたし，老人性難聴の 多くがこの病態である．腎陰虚には六味丸，腎陽虚には 牛車腎気丸が処方される.脾気虚の際も耳鳴をきたすこ とがあり，半夏白术天麻湯が処方される．また，高血圧 の病機は肝陽上立, 肝腎陰虚, 陰陽両虚である，頭痛の 病機は肝陰不足, 肝火上炎, 脾虚, 腎虚である.したが って，頭痛・高血圧をともなら耳鳴は，肝陽上妄のみで はなく，肝火上炎，腎虚なども考えられる。

高血圧・頭痛のある人に釣藤散を処方することは適応 を守った使用方法であるが，高血圧・頭痛の有無では有 意差を認めなかった．他の病機の耳鳴もあるので，高血 圧・頭痛のみでは指標が不足していると考える．70歳以 上に有効であることは，1つの指標となることを示唆す る. 今回のC群は, 高血圧・頭痛のほか, 肩こり, 眠り が浅い, 目の充血などの肝気の上昇した症状, 食欲がな い, 疲れやすいなどの脾虚の症状があり, 夜間頻尿, 下 肢の冷克などの腎虚の症状が乏しいこと, 舌診では舌質 やや紅で苔はじ苔であることを参考にして処方した。こ れらの所見が一人の患者にすべてにそろっては拈らず， また客観的に捉えにくい所見もある、釣藤散で耳鳴を治 療する場合は, 耳鳴は保険適応にない症状であるので, 適応を守り頭痛・高血圧を指標とすることは大切である が，適応は証の一部にしか過ぎない，今後の医療をとり まく環境を考慮すれば，証を守って処方しなければいけ ない時代になる可能性がある.したがって, 誰もが捉兄 
やすい指標となる適応以外の所見を決めることが一般の 耳鼻咽喉科医にとって望まれる。

\section{参考文献}

1) 田口喜一郎：耳鳴治療に批ける漢方薬の意義 一西洋薬と の併用療法一. Prog Med $10: 2458 \sim 2463,1990$.
2 ) 石戸谷淳一, 田中智加子, 鳥山 稔, 他：耳鳴に対する釣 藤散の使用経験. Prog Med 13 : 1747 1753, 1993.

3 ) 早川貴美子, 深間内麻木, 山川卓也, 他 : 当科に批る耳 鳴に対する釣藤散の臨床的評価. Prog Med 15:2575〜 2579, 1995.

4 ）小形 章, 神崎 七, 大内利昭, 他 : 耳鳴に対する柴胡桂 枝湯の効果. Prog Med 15 : 2584 2586, 1995. 